\title{
Simultaneous measurement of metabolic activity and membrane integrity in marine bacterioplankton determined by confocal laser-scanning microscopy
}

\author{
Heidemarie Pirker, Clemens Pausz, Karen E. Stoderegger, Gerhard J. Herndl*
}

Department of Biological Oceanography, Royal Netherlands Institute for Sea Research (NIOZ), PO Box 59, 1790 AB Den Burg, The Netherlands

\begin{abstract}
We simultaneously assessed the metabolic activity and viability of individual bacterioplankton cells in the coastal and open North Sea. Three different techniques were applied to determine cell features related to the physiological status of the cell. SYBR Green I was used to estimate the nucleic acid content of the cell. Propidium iodide (PI) stains cells with a compromised cell membrane, commonly interpreted as indicative of dead cells. Microautoradiography (MA) with radiolabeled glucose and leucine was applied to indicate metabolically active cells. The relative abundance of metabolically active cells determined by MA was usually $<20 \%$ of the total abundance of bacteria. In contrast, the percentage of PI-positive cells in the total bacterial community was generally high $(\sim 80 \%)$. However, the overwhelming majority $(97 \%)$ of cells taking up glucose and leucine were also PI-positive. Apparently, the uptake of radiolabeled substrate is related to PI accumulation in cells, indicating that PI is not a reliable stain to indicate non-active or dead bacteria. We suggest that several methods should be combined to assess the physiological status of individual cells in natural bacterioplankton communities.
\end{abstract}

KEY WORDS: Bacteria $\cdot$ Propidium iodide method - Microautoradiography $\cdot$ Active versus dead · Metabolic activity $\cdot$ Single cell analysis

\section{INTRODUCTION}

Most of the methods used to determine bacterial abundance are based on staining bacteria with a fluorescent marker and subsequent enumeration by epifluorescence microscopy (Hobbie et al. 1977) or flow cytometry (Gasol \& Del Giorgio 2000). The physiological status of bacteria is more difficult to determine. There is some consensus now that not all the nucleic acid stainable bacteria are equally active (LopezAmoros et al. 1995, Choi et al. 1996). Individual members of a bacterioplankton community obviously exhibit a wide range of metabolic activity, probably representing an activity continuum of bacterial cells in natural environments ranging from highly active to ultimately dead cells. Applying various methods, it has been shown that at any given time a significant frac- tion of bacterioplankton communities has minimal or no metabolic activity (Del Giorgio \& Scarborough 1995, Zweifel \& Hagström 1995, Heissenberger et al. 1996, Choi et al. 1999, Sherr et al. 1999a,b).

The methods commonly used to determine the proportion of active cells focus on parameters such as membrane integrity (Williams et al. 1998), the presence of a nucleoid (Zweifel \& Hagström 1995), respiratory activity (Choi et al. 1999), or, less widely used, the uptake of radiolabeled substrate using microautoradiography (Howard-Jones et al. 2001). One of the most widely used fluorescent stains to assess compromised cell membranes besides SYTOX is propidium iodide (PI), a nucleic acid stain thought to be impermeable when the cell membrane is intact. Cells in which PI is accumulating due to intercalation with nucleic acid appear red under blue excitation and 
are commonly defined as dead cells (Jernaes \& Steen 1994, Steen et al. 1994, Lopez-Amoros et al. 1995, 1997, Williams et al. 1998). PI has been widely used to assess the fraction of dead cells in aquatic bacterial communities, often in combination with other fluorescent stains targeting the respiratory chain of bacteria and thus actively respiring cells, such as cyano-ditolyltetrazolium chloride (CTC) (Schumann et al. 2003).

Microautoradiography as a tool to assess the uptake of radiolabeled substrates is less frequently used to indicate single-cell activity, probably because it is more laborious and time-consuming than the application of fluorescent stains (Meyer-Reil 1978, Carman 1990, Karner \& Fuhrman 1997). Applying several of these methods concurrently may allow discrimination of different physiological stages of cells. Metabolically active cells can be distinguished from dormant cells, which are not active at the time of sampling but have the potential of becoming active or either dead or 'ghost' cells (Lebaron et al. 2001). The relative proportions of these groups vary in natural communities. Estimates on the proportion of dead and low-activity cells range from 0.1 to $99 \%$, depending on the method used and the environment (Lovejoy et al. 1996, Karner \& Fuhrman 1997, Sherr et al. 1999b). The extent to which such a wide range of active or dead cells is real or due to the applied methods is a matter of debate.

The aim of the present study was to simultaneously assess the metabolic activity and viability on a singlecell level using a correlative approach. We combined 3 different techniques to determine cell features characteristic of the physiological status of cells: (1) the cellular nucleic acid content, (2) membrane integrity and (3) the uptake of radiolabeled glucose and leucine. Total bacterial abundance was determined via detection of the nucleic acid content. Uptake of substrate indicates metabolically active cells and was detected by microautoradiography (MA), while membrane integrity was visualized by applying PI and detecting its accumulation within the cell. PI-positive (PI+) cells were assumed to be dead.

\section{MATERIALS AND METHODS}

Study site and sample collection. Seawater was collected from 6 stations in the North Sea in the spring and early summer of 2002 (Fig. 1). Stn 0 is a coastal station situated at the western entrance of the North Sea to the Dutch Wadden Sea and is characterized by strong tidal currents. At Stn 0, incoming North Sea water was collected during high tide at $0.5 \mathrm{~m}$ depth in April and June of 2002. Stns 1 to 5 were sampled dur- ing the MOMAP-1 cruise of RV 'Pelagia' between 19 April and 3 May 2002. Stn 1 is located off the Schelde estuary (Fig. 1). Stns 2 to 5 are situated in the central North Sea. Stns 1 to 5 were sampled at $5 \mathrm{~m}$ depth with 101 NEOX bottles mounted on a Seabird-CTD rosette sampler.

Sample processing to assess the physiological status of bacterial cells. Water samples were pre-filtered through $0.8 \mu \mathrm{m}$ pore-size polycarbonate filters (Millipore) to remove most of the non-bacterial particles. Duplicate $10 \mathrm{ml}$ samples and 1 control were incubated with $10 \mathrm{nM} \mathrm{L}-\left[4,5-{ }^{3} \mathrm{H}\right]$-leucine (specific activity $73.0 \mathrm{Ci}$ $\mathrm{mmol}^{-1}$, Amersham) or $20 \mathrm{nM}$ of $\mathrm{D}-\left[{ }^{3} \mathrm{H}\right]$-glucose (specific activity $30 \mathrm{Ci} \mathrm{mmol}^{-1}$, Amersham) at in situ temperature for $4 \mathrm{~h}$. Controls were fixed with formaldehyde ( $3 \%$ final concentration) $10 \mathrm{~min}$ prior to adding the tracer. After incubation, the unfixed samples and the formaldehyde-fixed controls were filtered onto $0.2 \mu \mathrm{m}$ pore-size polycarbonate filters $(25 \mathrm{~mm}$, Millipore) supported by $0.45 \mu \mathrm{m}$ nitrocellulose filters (Millipore). Subsequently, the filters were covered with

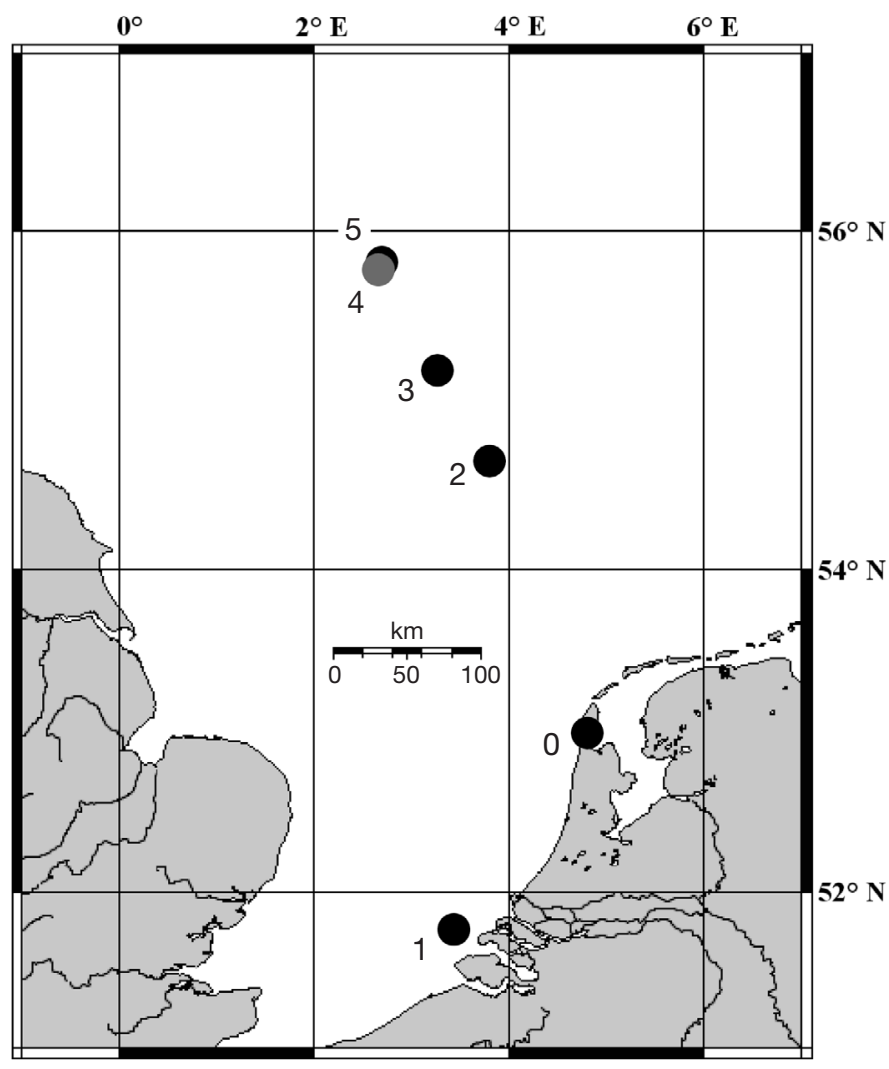

Fig. 1. Map of the study area in the North Sea. Stations are indicated by circles. Stn 0 is the nearshore sampling site at the NIOZ jetty on the island of Texel (The Netherlands), sampled in April and June 2002. During the MOMAP-1 cruise, Stn 1, a coastal site off the Schelde estuary and sites in the open North Sea (Stns 2 to 5) were sampled 
propidium iodide (PI, Molecular Probes) dissolved in Milli-Q water (final concentration: $0.6 \mu \mathrm{g} \mathrm{m} \mathrm{m}^{-1}$ ) and allowed to stain at in situ temperature for $30 \mathrm{~min}$. Thereafter, excess PI was removed by filtration, and the filter was rinsed with Milli-Q water. SYBR Green I (Molecular Probes) was added to obtain a final dilution of 1:400 following the recommendation of the manufacturer. After $15 \mathrm{~min}$, the filters were rinsed twice with Milli-Q water. Filters taken onboard were stored frozen in the dark at $-20^{\circ} \mathrm{C}$ and processed upon return to the laboratory within 2 wk. Samples collected at Stn 0 were processed immediately.

Formaldehyde-fixed controls were run to check for potential accumulation of silver grains around dead cells. Thus, these fixed controls served as an additional check for cells that were definitely inactive. No accumulation of silver grains around formaldehyde-fixed cells was detected.

We added the Milli-Q water PI solution directly to the bacteria collected on the filter and rinsed the filter after the filtration step with Milli-Q to remove excess PI. In the original protocol, the Milli-Q-PI solution was added after a $2 \%$ methanol fixation step (HowardJones et al. 2001). Comparing the percentage of PI+ cells in samples treated with $2 \%$ methanol and without methanol prior to adding the Milli-Q-PI solution, we found no significant difference between the 2 treatments (Wilcoxon, $\mathrm{p}=0.853, \mathrm{n}=6$ ).

Microautoradiography. In the darkroom kept at $15^{\circ} \mathrm{C}$, the photographic emulsion (Type NTB-2, Kodak) was melted in a water bath set at $43^{\circ} \mathrm{C}$ for $1 \mathrm{~h}$. Afterwards, the emulsion was mixed with ultrapure water (Sigma) at a 1:3 (vol/vol) ratio, aliquoted into small portions $(10.5 \mathrm{ml})$ and stored at $4^{\circ} \mathrm{C}$. Each aliquot was melted only 3 times. The slides were prepared by dipping them into a 1:1 solution of melted emulsion (at $43^{\circ} \mathrm{C}$ for $\left.15 \mathrm{~min}\right)$ and a gelatin solution $(0.02 \%$ gelatin, $0.02 \% \mathrm{CrKSO}_{4}$ ). Thereafter, the slides were placed on an ice-cold aluminum bar to solidify for $10 \mathrm{~min}$. Coating of the slides was done in complete darkness. Transfer of the filter sections into the emulsion was done under a $15 \mathrm{~W}$ lamp using a safelight red filter (Hama 8194). The polycarbonate filters were placed upside down on the coated slides and dried in the dark for $30 \mathrm{~min}$. The slides were placed in a light-tight box with silica-gel as a drying agent and exposed at $4^{\circ} \mathrm{C}$ for $72 \mathrm{~h}$. Thereafter, slides were developed using Dektol developer (Kodak), a Milli-Q water stop-bath and fixer (Kodak), according to the manufacturer's specifications. Slides were placed into the developing solution for $10 \mathrm{~min}$, stopped with Milli-Q water for $10 \mathrm{~s}$ and fixed for $5 \mathrm{~min}$. After a wash in Milli-Q water for $2 \mathrm{~min}$, slides were dried over night in a desiccator. Filters were peeled off after marking their position on the slide with a waterproof pen. A mounting solution (Citi- fluor, AF1) was placed on the marked area and covered with a coverslip. The recovery efficiency of cells after the microautoradiography treatment was on average $78 \pm 14 \%$ of the bacterioplankton stained with SYBR Green I.

As we followed a standard procedure with fixed incubation times with radiolabeled substrates $(4 \mathrm{~h})$ and exposure time $(72 \mathrm{~h})$ for the microautoradiography, we were able to compare the extent of the resulting silvergrain halos surrounding active cells between different samples.

Semiautomated confocal laser scanning microscopy. The stained samples were examined under a confocal laser-scanning microscope (CLSM, Zeiss). Multitrack laser scanning (frame mode) was used to avoid fluorescence overlapping and a PlanNeofluor $100 \times 1.3$ oil objective for image acquisition. For the detection of the SYBR Green I stained cells, an Argon laser (488 $\mathrm{nm}$ wavelength) was used, and signal detection was achieved using a BP 505-530 filter. For PI, a Helium Neon-1 laser (543 nm) and a BP 585-615 filter were applied. Microautoradiographic counts were made under transmitted light. For the entire sampling period, detector gain, amplitude gain and amplitude offset were adjusted only once, and laser intensities were standardized as described below. Therefore, for each experiment, only the laser intensities were re-adjusted for each image to ensure that the gray-scale of the images never exceeded 256 (image depth: 8 bits).

Image analysis. For image analysis, the Zeiss KS 300 software package was used. On the combined 3-channel image, the area of each individual bacterial cell was determined, and, subsequently, the threshold levels for the 3 channels were adjusted separately for this area. The images were checked for detected cells and eventually corrected by excluding non-bacterial particles or adding bacteria originally not detected by the channel settings. Per sample, a total of 15 images (10 to 30 bacteria per image) was taken.

Standard preparation. The stability of the laser over time and the linearity of the fluorescence signal with increasing laser intensity were checked with standard fluorescent beads (InSpeck, diameter = $2.5 \mu \mathrm{m}, 0.3 \%$ relative fluorescence, Molecular Probes, I-7219, I-7224). These fluorescent beads were tested under the specific CLSM settings at the beginning and about half way through the analysis using the single-track option from the lowest possible (min. gray scale $>20$ ) to the highest possible laser intensity (max. gray scale 256). For the Argon laser (488 nm) InSpeck Green (Ex/Em: 505/515 nm) and for the HeliumNeon-1 laser (543 nm) InSpeck Red (Ex/Em: $580 / 605 \mathrm{~nm}$ ) were used. 


\section{RESULTS}

\section{Evaluation of the techniques used to assess the physiological status of bacterial cells}

Fig. 2 shows a representative image taken from water collected at Stn 0 in June assessing the physiological status of single cells by combining the 3 different techniques and thereby targeting different cellular characteristics. Staining of the nucleic acids using SYBR Green I (Fig. 2a) was combined with microautoradiography using glucose (Fig. 2b) or leucine as substrate to indicate metabolically active cells. The dark halos (Fig. 2b) surrounding the cells indicate radioactively reduced silver grains. PI staining should be indicative of compromised cell membranes (Fig. 2c). As shown in Fig. 2d, some cells were recorded as $\mathrm{PI}+$, but they actively incorporated organic substrate.
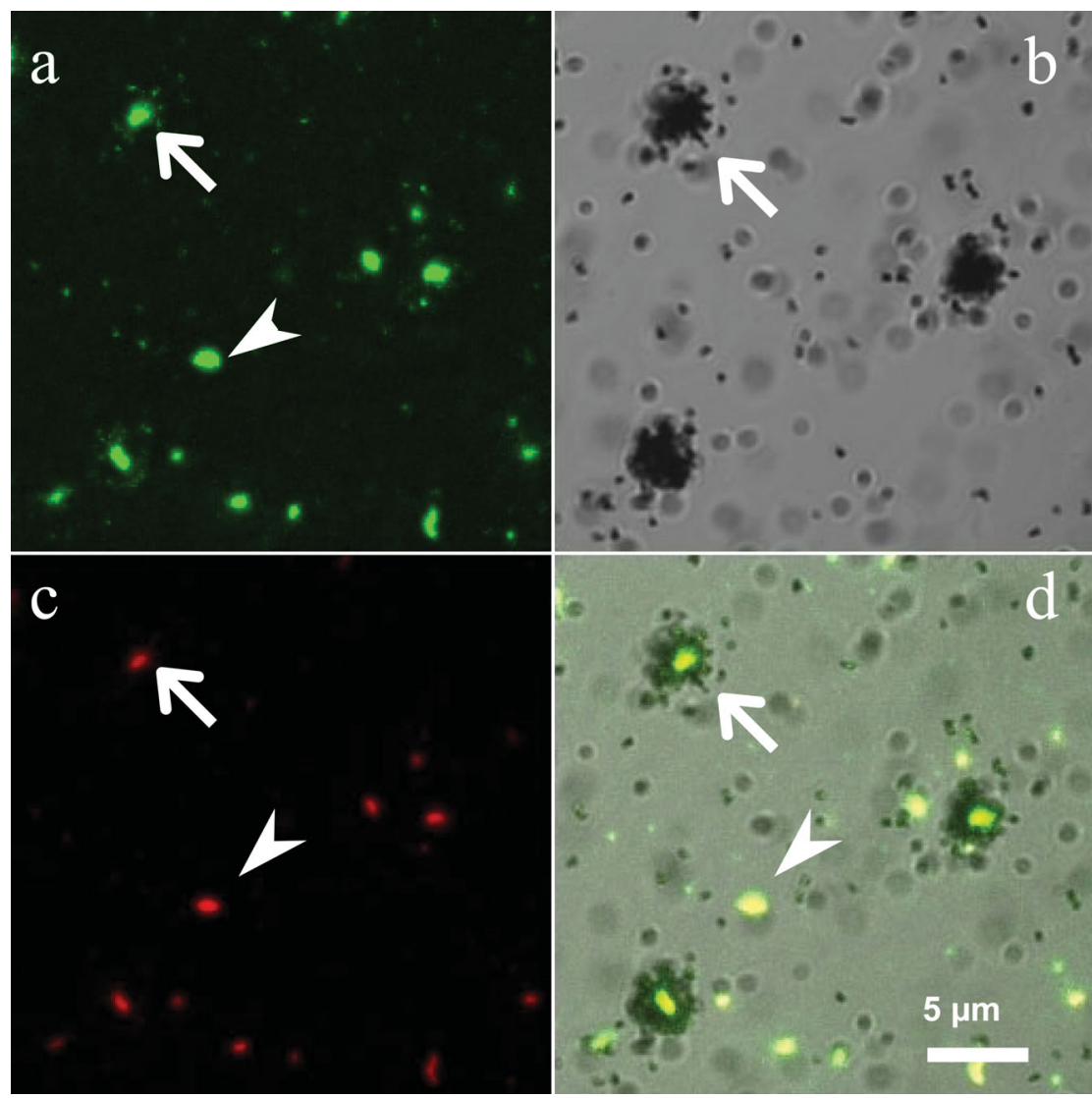

Fig. 2. Image obtained by confocal laser-scanning microscope (Stn 0, 14 June 2002) showing: (a) SYBR Green I stained bacteria, (b) microautoradiography image, (c) propidium iodide stained (PI+) cells, and (d) a composite image of panels (a) to (c). The microautoradiographic image was taken in transmission mode, the dark silver-grain halos around the cells indicate uptake of radiolabeled glucose. Arrowhead marks a PI+ cell not taking up glucose; arrow indicates a PI+ cell surrounded by a halo indicating uptake of glucose

\section{Contribution of PI+ and active cells to the bacterial community}

The contribution of PI+ cells to the total bacterial community was generally high in the North Sea during the spring (Fig. 3). At the nearshore station (Stn 0), the fraction of PI+ cells, averaged over the investigation period, was $77 \pm 12 \%$ (Fig. 3a). Within about $1 \mathrm{wk}$, the relative abundance of PI+ cells increased from 63 to $90 \%$ of total bacterial abundance (12 April) and declined again towards the summer (Fig. 3a). At the open North Sea stations, the fraction of PI+ cells was, on average, $83.4 \pm 3.3 \%$ of the total bacterial abundance (Fig. 3b).

The relative abundance of active cells as determined by the uptake of radiolabeled glucose and leucine using MA was usually $<20 \%$ of the total bacterial cells at Stn 0 (Fig. 3a). Only in mid-June did the percentage of active cells increase to 32 and $24 \%$ for glucose and leucine uptake, respectively (Fig. 3a). On average, at Stn 0 , the fraction of active cells was $17.9 \pm 8.0 \%$ for glucose and $18.7 \pm 5 \%$ for leucine incorporation. No significant differences were detectable between the percentage of bacteria taking up glucose or leucine (Wilcoxon, $\mathrm{p}=$ $0.7, \mathrm{n}=5$ ).

At the open North Sea stations (Stns 1 to 5) (Fig. 3b), the percentage of active cells was not significantly different to that obtained for Stn 0 (Fig. 3a). Mean percentages for glucose- and leucine-active cells were $16.1 \pm 9.1 \%$ and $13.1 \pm$ $7.6 \%$, respectively, of the total bacterial abundance (Fig. 3b). As for Stn 0, no significant difference was found between the percentage of cells taking up glucose and those taking up leucine (Wilcoxon, $\mathrm{p}=0.7, \mathrm{n}=5$ ). The highest fraction of active cells in the open North Sea was found at Stn 1, with $27.2 \%$ of the total bacterial abundance incorporating glucose, while the fraction incorporating leucine was only $13.5 \%$ of the total bacterial abundance (Fig. 3b). The lowest overall contribution of cells incorporating glucose and leucine was found at Stn 5 , with $3.0 \%$ and $4.4 \%$ of the total bacterial abundance, respectively (Fig. 3b). 

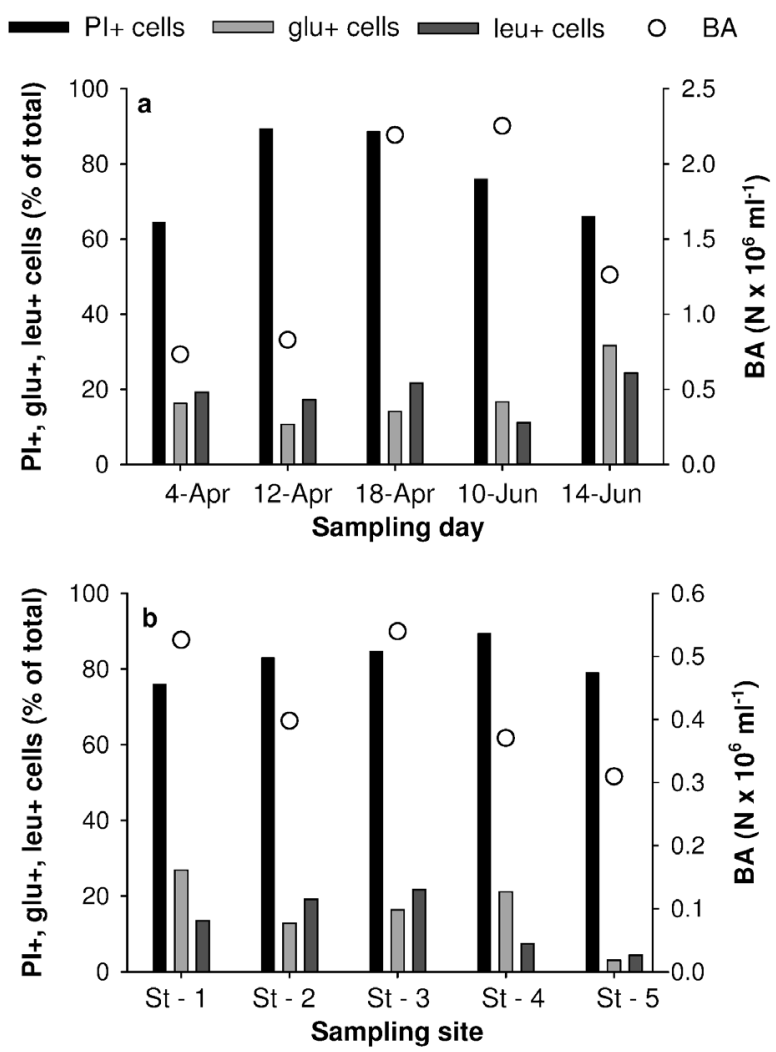

Fig. 3. Proportion of propidium iodide-positive (PI+) cells and cells taking up glucose (glu+) or leucine $(\mathrm{leu}+)$ of the total bacterial community, as revealed by microautoradiography at: (a) Stn 0 and (b) Stns 1 to 5 during the MOMAP-1 cruise.

The total bacterial abundance (BA) is also given

\section{Distribution of activity of individual members of the bacterioplankton community based on microautoradiography}

By quantifying the areal extension of the silvergrain halo surrounding metabolically active cells using CLSM and image analysis we were able to distinguish different activity levels on a single-cell basis (Fig. 4). Generally, within the bacterial community exhibiting metabolic activity, a large temporal (Fig. 4a,b) and spatial variability (Fig. 4c,d) in the activity level was detectable. At the nearshore station (Stn 0), most of the bacterial cells taking up glucose and leucine were in the halo area classes $>3.5 \mu^{2}$, contributing between 14 and $63 \%$ to the total number of active bacteria (Fig. 4a,b), and were considered as highly active. The notable exception was on 12 April, when bacteria were primarily distributed among the smaller areal classes, indicating a larger contribution of less active cells to the total bacterial community (Fig. 4a,b).

From the open North Sea Stns 2, 3 and 5, a similar, variable activity distribution was obtained for the different size classes, as was also true for the nearshore station (Fig. 4c,d). The relative abundance of the different size classes of Stns 1 and 4 was dominated, however, by the smaller size classes $\left(<2 \mu \mathrm{m}^{2}\right)$, contributing occasionally up to $80 \%$ to the total abundance of active bacteria (Stn 4, Fig. 4c).

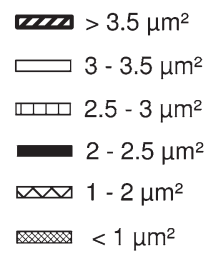

Fig. 4. Contribution of the different areal classes of the silver-grain halo surrounding cells taking up glucose $(\mathrm{a}, \mathrm{c})$ or leucine $(\mathrm{b}, \mathrm{d})$ to the total number of active bacteria at Stn $0(a, b)$ and at Stns 1 to $5(\mathrm{c}, \mathrm{d})$ (rA: relative abundance in percentage of active cells)
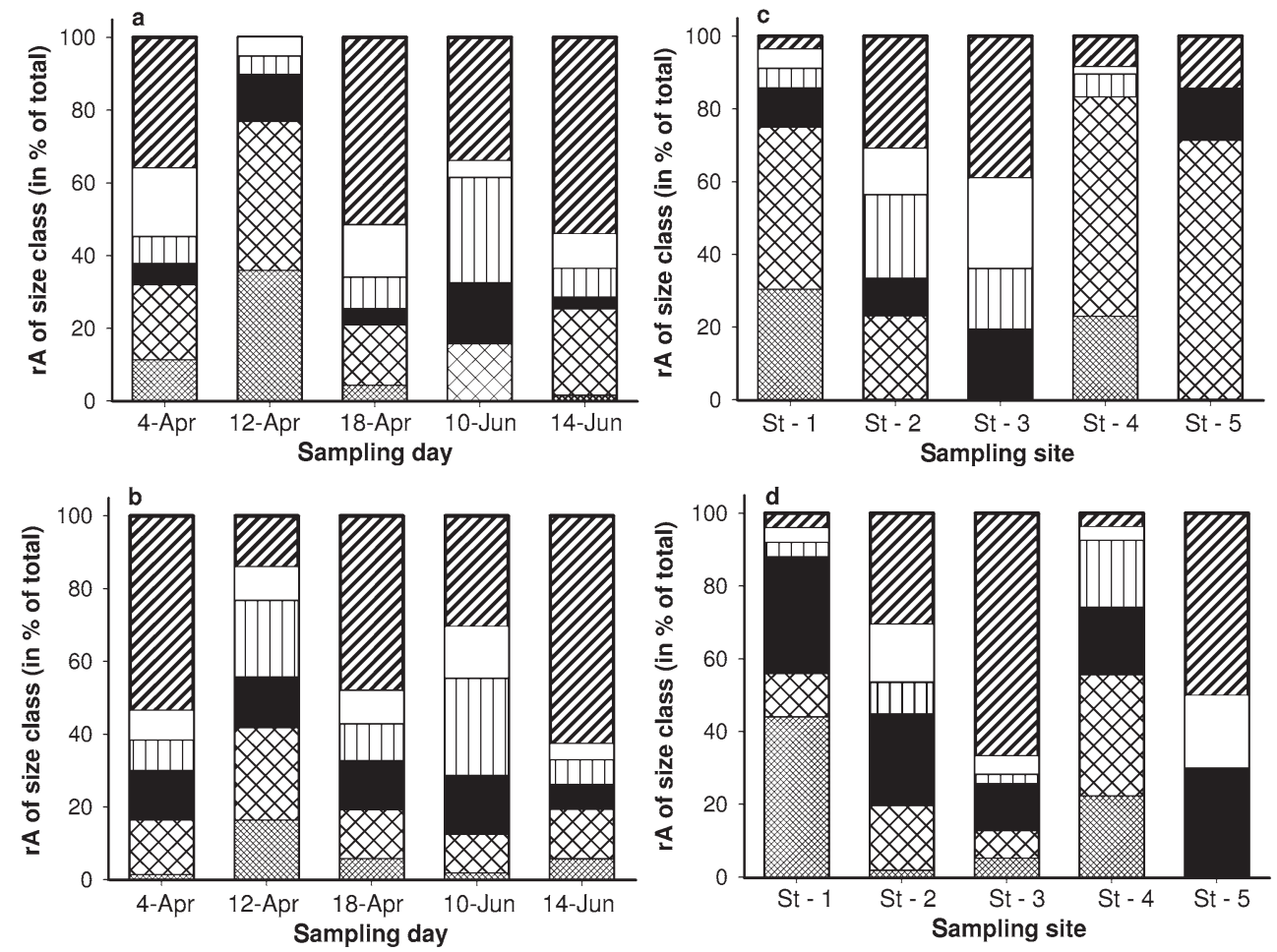


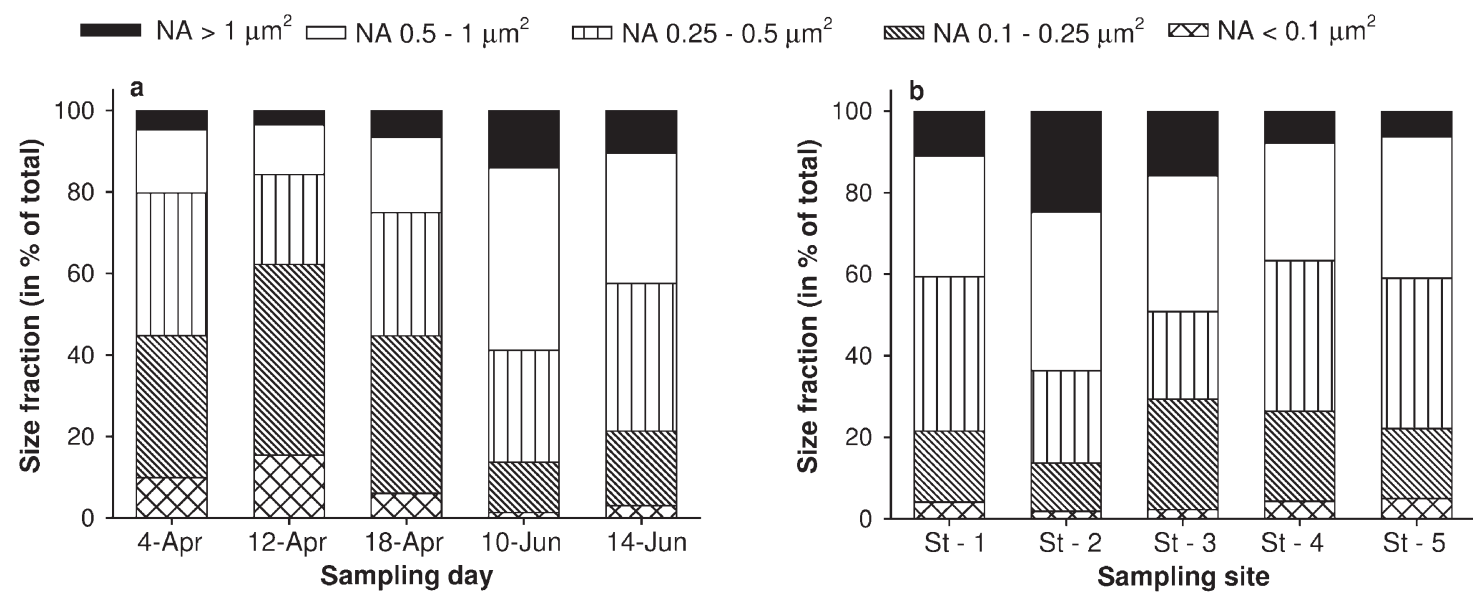

Fig. 5. Contribution of different areal classes of the nucleic acid (NA) stained area (by SYBR Green I) to the total abundance of bacteria for: (a) Stn 0 and (b) Stns 1 to 5

\section{Single-cell distribution of the nucleic acid stained area in bacterial communities}

At Stn 0, bacterial cells with a nucleic acid (NA)stained area of $<0.25 \mu^{2}$ made up about half of the total bacterial cells present in April (Fig. 5a). However, the fraction of cells with an NA area of $<0.25 \mu^{2}$ decreased to $<25 \%$ of the total bacterial cells in June, with a concomitant increase in the contribution of cells with an NA area of $>0.5 \mu^{2}$. At the open North Sea stations, the fraction of cells with a small NA area $\left(<0.25 \mu^{2}\right)$ was 10 to $40 \%$ of the total bacterial abundance (Fig. 5b). Stns 2 and 3 exhibited the highest fractions of cells $(\sim 70 \%)$ with a NA area of $>0.5 \mu \mathrm{m}^{2}$.

The relation between the NA area and the area of the halo obtained by microautoradiography was generally weak (data not shown). Also the relation between the NA fluorescence intensity and the halo area obtained by microautoradiography was weak $\left(r^{2}=0.240\right.$ to 0.504 , data not shown).

\section{DISCUSSION}

The aim of this study was to evaluate different methods indicating active versus non-active or dead cells in natural bacterioplankton assemblages. We assume that substrate uptake measured by radiotracers is a reliable indicator for metabolically active cells, and glucose and leucine have been shown to be taken up by almost all active bacteria (Meyer-Reil 1978, Karner \& Fuhrman 1997, Cottrell \& Kirchman 2003). The 2 other methods used in this study both target nucleic acids. While SYBR Green I was used to estimate the nucleic acid content of the cell, which is a prerequisite for an active cell, PI was used as an indicator of cells with a compromised cell membrane. By applying first the PI and then SYBR Green I, we used a sequential staining protocol, rather than the competitive staining approach proposed by Gregori et al. (2001), and compared the resulting stains with microautoradiography. Testing whether there is a difference between the competitive and the sequential staining protocol, we found that the sequential staining protocol resulted in an insignificantly higher percentage of PI+ cells than the competitive staining approach (Wilcoxon, $\mathrm{p}=$ 0.374, $\mathrm{n}=6$ ). In general, PI+ cells are defined as dead cells (Williams et al. 1998, Schuman et al. 2003). However, as shown in Fig. 2, we found cells capable of taking up organic substrate while at the same time exhibiting red fluorescence, indicating accumulation of PI inside the cell.

\section{PI-an indicator of 'dead cells'?}

As shown in Fig. 6, a substantial fraction of all the individual cells examined took up radiolabeled glucose or leucine and PI (mean: $16.1 \pm 7.1 \%$ ). In contrast, only a rather small fraction of cells (up to $3 \%$ of the total cells) could be classified as active (i.e. a silvergrain halo around the cell) and not accumulating PI at the same time (Fig. 6). Thus, the overwhelming majority of cells taking up glucose and leucine are also accumulating PI. PI+ cells not taking up glucose or leucine amounted to $63.6 \pm 13.4 \%$ of the total bacterial abundance, thus being scored as inactive by both methods (Fig. 6). This indicates that highly active cells transporting substrate across the cell membrane are also taking up PI. Thus, PI+ cells in natural samples might not accurately reflect the number of inactive or dead cells. Our results indicate that bacteria from natural environments are more permeable for PI-based stains than previously assumed. Commonly, the reliability of 

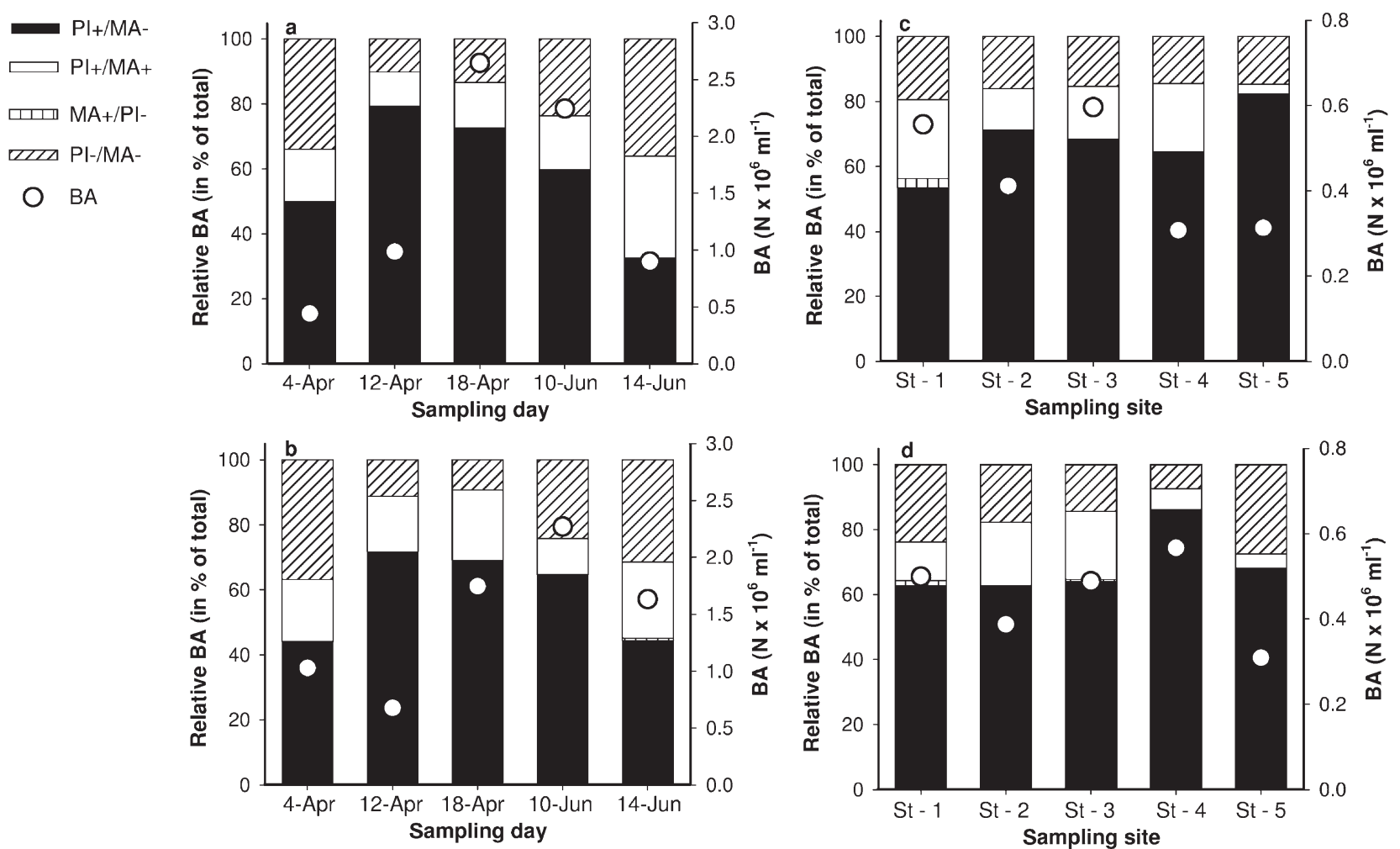

Fig. 6. Percent contribution of PI+ cells only (PI+/MA-, propidium-iodide positive/microautoradiography-negative), PI+ cells but active (PI+/MA+), active PI- cells (MA+/PI-) and PI- inactive cells (PI-/MA-) to the total bacterial abundance (BA) at Stn 0 (a, b) and at Stns 1 to 5 (c, d). Active cells are those surrounded by a silver-grain halo after microautoradiography with glucose (a, c) or leucine $(\mathrm{b}, \mathrm{d})$

PI as an indicator of compromised cell membranes has been frequently tested on cultured bacteria using frequently heat-killed bacteria to check PI accumulation (Lopez-Amoros et al. 1995, Williams et al. 1998). To our knowledge, this is the first report combining microautoradiography with PI-staining.

The mean percentage of $63 \%$ of PI+/MA- cells (nonactive with both methods) of the total bacterioplankton abundance corresponds roughly with the recovery efficiency of bacterioplankton in the coastal North Sea using rRNA-targeting oligonucleotide probes and fluorescence in situ hybridization (FISH, 20 to $40 \%$ of DAPI-stained cells, Pernthaler et al. 2002a). However, this FISH method with fluorescently labeled oligonucleotide probes has been substantially improved recently (Pernthaler et al. 2002b), resulting in an overall recovery efficiency of $>70 \%$ of DAPI-stained cells for the study site (E. Sintes unpubl. data).

One of the critical aspects in the use of PI is the concentration of the stain, as pointed out by Williams et al. (1998). We used a PI concentration of $0.90 \mu \mathrm{M}$, Williams et al. (1998) recommend 1.49 to $7.48 \mu \mathrm{M}$, Schumann et al. (2003) used $3.3 \mathrm{mM}$ final PI concentration as recommended in the instructions for the viability kit LIVE/DEAD BacLight (Molecular Probes). High
PI concentrations result in a higher percentage of PI+ cells, as shown by Williams et al. (1998). Highly variable results using PI have also been reported by Berman et al. (2001). A high percentage of inactive cells has been reported by a number of authors using a large range of methods, and these papers tend to arrive at an inactive fraction of the bacterioplankton commonly $>50 \%$, occasionally up to $95 \%$ of the bacterioplankton cells would score as inactive (reviewed in Smith and Del Giorgio 2003). These high values of inactive cells may not be equated with dead cells, however, if we assume that the presence of rRNA in the cell indicates living cells.

\section{Dynamics of metabolically active bacteria in natural systems}

Despite the methodological problems outlined above, there is some consensus that not all the members of the bacterioplankton community are active at any given time. Cells might be in a dormant state when nutrient composition and/or concentration do not fulfill the species-specific requirements. Using the halo area of the silver grains surrounding active cells in the micro- 
autoradiography treatment as an indicator of activity levels (Fig. 4), an impression of the dynamics of activity levels can be obtained. The distribution pattern of the halo area around active cells using glucose (Fig. $4 \mathrm{a}, \mathrm{c}$ ) was rather similar to that obtained by leucine (Fig. 4b,d). The distribution of the activity levels of the nearshore bacterioplankton was similar to that of the open North Sea, although the highest activity class dominated more frequently in nearshore bacterioplankton. Considerable temporal (Fig. 4a,b) and spatial (Fig. 4c,d) variability in the activity levels was observed. This reflects most likely dynamics in the substrate composition of the dissolved organic matter pool and accompanied shifts in the phylogenetic composition of the bacterioplankton, as shown by Arrieta \& Herndl (2002) for the same study site. Overall, the data shown in Fig. 4 indicate that there is a dynamic continuum of activity levels in natural bacterioplankton communities, with a certain fraction of highly active cells co-occurring with cells exhibiting medium and low activity.

\section{CONCLUSIONS}

Based on the target metabolic parameter, different methods will reveal different contributions of the active or inactive fraction to the total bacterial abundance. If we assume further that there is a continuum of activity levels present in natural bacterioplankton assemblages, as suggested by, e.g., Berman et al. (2001), it is not surprising that large differences are reported in specific metabolic parameters for bacterioplankton communities. The lower range of metabolic activity still detectable varies with the method used. Only a combination of methods will allow us to accurately assess the number of active, inactive and dead cells. Most of the studies aiming at quantifying the number of active versus inactive or dead cells use a combination of techniques (see review of Vives-Rego et al. 2000). Nevertheless, our data indicate that results obtained even by the staining approach with SYBR Green I and propidium iodide, as proposed for natural communities by Gregori et al. (2001), should be interpreted with caution.

Acknowledgements. We thank the captain and crew of the RV 'Pelagia' for their support at sea and the chief scientist Corina Brussaard for inviting us to join her cruise (MOMAP-1). Funding was provided by the Dutch Science Foundation (project 805.37.324 to G.J.H.) and jointly by the EU projects COMET, AIRWIN and BASICS of the IMPACT cluster. This work is in partial fulfillment of the requirements for an M.S. degree from the University of Vienna, Austria, by H.P. We thank the anonymous reviewers for valuable suggestions resulting in additional tests.

\section{LITERATURE CITED}

Arrieta JM, Herndl GJ (2002) Changes in bacterial $\beta$-glucosidase diversity during a coastal phytoplankton bloom. Limnol Oceanogr 47:594-599

Berman T, Kaplan B, Chava S, Viner Y, Sherr BF, Sherr EB (2001) Metabolically active bacteria in Lake Kinneret. Aquat Microb Ecol 23:213-224

Carman KR (1990) Radioactive labeling of a natural assemblage of marine sedimentary bacteria and microalgae for trophic studies - an autoradiographic study. Microb Ecol 19:279-290

Choi JW, Sherr EB, Sherr BF (1996) Relation between presence and absence of a visible nucleoid and metabolic activity in bacterioplankton cells. Limnol Oceanogr 41: $1161-1168$

Choi JW, Sherr BF, Sherr EB (1999) Dead or alive? A large fraction of ETS-inactive marine bacterioplankton cells, as assessed by reduction of CTC, can become ETS-active with incubation and substrate addition. Aquat Microb Ecol 18:105-115

Cottrell MT, Kirchman DL (2003) Contribution of major bacterial groups to bacterial biomass production (thymidine and leucine incorporation) in the Delaware estuary. Limnol Oceanogr 48:168-178

Del Giorgio P, Scarborough G (1995) Increase in the proportion of metabolically active bacteria along gradients of enrichment in freshwater and marine plankton: implications for estimates of bacterial growth and production. J Plankton Res 17:1905-1924

Gasol JM, Del Giorgio PA (2000) Using flow cytometry for counting natural planktonic bacteria and understanding the structure of planktonic bacterial communities. Sci Mar 64:197-224

Gregori G, Citterio S, Ghiani A, Labra M, Sgorbati S, Brown S, Denis M (2001) Resolution of viable and membranecompromised bacteria in freshwater and marine waters based on analytical flow cytometry and nucleic acid double staining. Appl Environ Microbiol 67:4662-4670

Heissenberger A, Leppard G, Herndl GJ (1996) Relationship between the intracellular integrity and the morphology of the capsular envelope in attached and free-living marine bacteria. Appl Environ Microbiol 62:4521-4528

Hobbie J, Daley R, Jasper S (1977) Use of Nuclepore filters for counting bacteria by epifluorescence microscopy. Appl Environ Microbiol 33:1225-1228

Howard-Jones M, Frischer M, Verity P (2001) Determining the physiological status of individual bacterial cells. In: Paul JH (ed) Marine microbiology, Vol 30. Academic Press, San Diego, CA, p 176-205

Jernaes MW, Steen HB (1994) Staining of Escherichia coli for flow-cytometry-influx and efflux of ethidium-bromide. Cytometry 17:302-309

Karner M, Fuhrman J (1997) Determination of active marine bacterioplankton: a comparison of universal 16S rRNA probes, autoradiography, and nucleoid staining. Appl Environ Microbiol 63:1208-1213

Lebaron P, Servais P, Agogue H, Courties C, Joux F (2001) Does the high nucleic acid content of individual bacterial cells allow us to discriminate between active cells and inactive cells in aquatic systems? Appl Environ Microbiol 67:1775-1782

Lopez-Amoros R, Comas J, Vives-Rego J (1995) Flow cytometric assessment of Escherichia coli and Salmonella typhimurium starvation-survival in seawater using rhodamine 123, propidium iodide, and oxonol. Appl Environ Microbiol 61:2521-2526 
Lopez-Amoros R, Castel S, Comas-Riu J, Vives-Rego J (1997) Assessment of E. coli and Salmonella viability and starvation by confocal laser microscopy and flow cytometry using rhodamine 123, DiBAC4(3), propidium iodide, and CTC. Cytometry 29:298-305

Lovejoy C, Legendre L, Klein B, Tremblay JE, Ingram R, Therriault JC (1996) Bacterial activity during early winter mixing (Gulf of St Lawrence, Canada). Aquat Microb Ecol 10:1-13

Meyer-Reil L (1978) Autoradiography and epifluorescence microscopy combined for the determination of number and spectrum of actively metabolizing bacteria in natural waters. Appl Environ Microbiol 36:506-512

Pernthaler A, Preston CM, Pernthaler J, DeLong EF, Amann R (2002a) Comparison of fluorescently labeled oligonucleotide and polynucleotide probes for the detection of pelagic marine Bacteria and Archaea. Appl Environ Microbiol 68:661-667

Pernthaler A, Pernthaler J, Amann R (2002b) Fluorescence in situ hybridization and catalysed reporter deposition for the identification of marine Bacteria. Appl Environ Microbiol 68:3094-3101

Schumann R, Schiewer U, Karsten U, Rieling T (2003) Viability of bacteria from different aquatic habitats. II. Cellular fluorescent markers for membrane integrity and metabolic

Editorial responsibility: Karel Šimek, České Budějovice, Czech Republic activity. Aquat Microb Ecol 32:137-150

Sherr BF, Del Giorgio P, Sherr EB (1999a) Estimating abundance and single-cell characteristics of respiring bacteria via the redox dye CTC. Aquat Microb Ecol 18:117-131

Sherr EB, Sherr BF, Sigmon CT (1999b) Activity of marine bacteria under incubated and in situ conditions. Aquat Microb Ecol 20:213-223

Smith EM, Del Giorgio AA (2003) Low fractions of active bacteria in natural aquatic communities? Aquat Microb Ecol 31:203-208

Steen HB, Jernaes MW, Skarstad K, Boye E (1994) Staining and measurement of DNA in bacteria. Methods in cell biology, Vol 42. Academic Press, San Diego, CA, p 477-487

Vives-Rego J, Lebaron P, Nebe-von Caron G (2000) Current and future applications of flow cytometry in aquatic microbiology. FEMS Microbiol Rev 24:429-448

Williams SC, Hong Y, Danavall DCA, Howard-Jones MH, Gibson D, Frischer ME, Verity PG (1998) Distinguishing between living and nonliving bacteria: evaluation of the vital stain propidium iodide and its combined use with molecular probes in aquatic samples. J Microbiol Methods 32:225-236

Zweifel U, Hagström A (1995) Total counts of marine bacteria include a large fraction of non-nucleoid-containing bacteria (ghosts). Appl Environ Microbiol 61:2180-2185

Submitted: July 25, 2004; Accepted: March 14, 2005

Proofs received from author(s): May 27, 2005 